\title{
Percutaneous ultrasound-guided versus bronchoscopy-guided dilatational tracheostomy after median sternotomy: A case-control study
}

\author{
Median sternotomi sonrası ultrason kılavuz/uğunda veya bronkoskopi kılavuzluğunda \\ perkütan dilatasyonel trakeostomi: Olgu kontrol çalısması

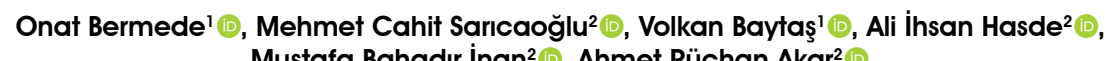 \\ Mustafa Bahadır İnan ${ }^{2}$, Ahmet Rüçhan Akar ${ }^{2}$ (B) \\ 'Department of Anesthesiology and Reanimation, Ankara University Faculty of Medicine, Ankara, Turkey \\ ${ }^{2}$ Department of Cardiovascular Surgery, Ankara University Faculty of Medicine, Ankara, Turkey
}

\begin{abstract}
Background: In this study, we aimed to compare ultrasoundguided versus bronchoscopy-guided percutaneous dilatational tracheostomy outcomes in critically ill adult patients undergoing a median sternotomy.
\end{abstract}

Methods: Between January 2015 and December 2020, a total of 54 patients (17 males, 37 females; mean age: $54.9 \pm 13.1$ years; range, 39 to 77 years) who underwent elective ultrasound- or bronchoscopy-guided percutaneous dilatational tracheostomy after a median sternotomy were included. We compared the ultrasound-guided group $(\mathrm{n}=25)$ with the bronchoscopy-guided group $(n=29)$ regarding all-cause mortality and complications. Safety assessments included major and minor bleeding, procedural hypoxic or hypotensive event, cardiac dysrhythmias, tracheal injury, damage to adjacent structures, and requirement of conversion to open surgical tracheostomy.

Results: No tracheostomy procedure-related death was observed in either group. The median time for tracheostomy was 13 (range, 8 to 17) $\mathrm{min}$ in the ultrasound-guided group and 10 (range, 7 to 15$) \mathrm{min}$ in the bronchoscopy-guided group ( $\mathrm{p}=0.387)$. There was no need for conversion between the two methods or conversion to surgical tracheostomy for any patient. The overall complication rates did not significantly differ between the groups $(\mathrm{p}=0.15)$.

Conclusion: Ultrasound-guided percutaneous dilatational tracheostomy can be safely performed in patients undergoing sternotomy. Complication rates of the procedure are similar to those guided with bronchoscopy.

Keywords: Airway, percutaneous dilatational tracheostomy, safety, ultrasonography.

\section{$\ddot{O} Z$}

Amaç: Bu çalışmada median sternotomi yapılmış erişkin kritik hastalarda, ultrason kılavuzluğunda ve bronkoskopi kılavuzluğunda yapılan perkütan dilatasyonel trakeostomi sonuçları karşılaştırıldı.

Çalışma planı: Ocak 2015 - Aralık 2020 tarihleri arasında median sternotomiden sonra elektif olarak ultrason veya bronkoskopi kılavuzluğunda perkütan dilatasyonel trakeostomi uygulanan toplam 54 hasta (17 erkek, 37 kadın; ort. yaş:

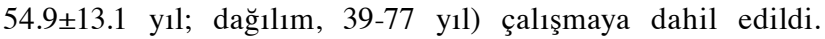
Ultrason kılavuzluğu grubu $(n=25)$ ve bronkoskopi kılavuzluğu grubu (n=29) tüm nedenlere bağlı mortalite ve komplikasyonlar açısından karşılaştırıldı. Güvenlik değerlendirmeleri arasında majör ve minör kanama, işlem ile ilgili hipoksik veya hipotansif olay, kardiyak disritmiler, trakeal yaralanma, komşu yapılarda hasar ve açık cerrahi trakeostomiye dönme gerekliliği yer aldı.

Bulgular: Grupların hiçbirinde trakeostomi ile ilişkili ölüm gözlenmedi. Trakeostomi için medyan süre, ultrason kılavuzluğunda 13 (dağılım, 8-17) dk. ve bronkoskopi kılavuzluğunda 10 (dağılım, 7-15) dk. idi ( $\mathrm{p}=0.387$ ). Hiçbir hastada iki yöntem arasında değişim veya cerrahi trakeostomiye geçiş gereksinimi olmad1. Genel komplikasyon oranları, gruplar arasında anlamlı düzeyde farklılık göstermedi $(\mathrm{p}=0.15)$.

Sonuç: Ultrason kılavuzluğunda perkütan dilatasyonel trakeostomi, sternotomi yapilan hastalarda güvenli bir şekilde yapılabilir. İşlemin komplikasyon oranları, bronkoskopi kılavuzluğunda yapılanlar ile benzerdir.

Anahtar sözcükler: Hava yolu, perkütan dilatasyonel trakeostomi, güvenlilik, ultrasonografi.

Received: April 26, 2021 Accepted: July 11, 2021 Published online: October 20, 2021

Correspondence: Onat Bermede, MD. Ankara Üniversitesi Tıp Fakültesi, Anesteziyoloji ve Reanimasyon Anabilim Dalı, 06590 Cebeci, Ankara, Türkiye. Tel: +90 505 - 6374404 e-mail: onatbermede@hotmail.com

Bermede O, Sarıcaoğlu MC, Baytaş V, Hasde Al, Inan MB, Akar AR. Percutaneous ultrasound-guided versus bronchoscopy-guided dilatational tracheostomy after median sternotomy: A case-control study. Turk Gogus Kalp Dama 2021;29(4):457-464 
Percutaneous dilatational tracheostomy (PDT) has been widely used to increase patient comfort and avoid complications in those who need long-term intubation with a safety profile, compared to surgical tracheostomy. ${ }^{[1]}$ Currently, various PDT modalities have evolved to reduce the incidence of complications. ${ }^{[2]}$ Early complications of PDT include bleeding, airway loss, tracheal wall injury, tracheal ring fracture, damage to adjacent structures, pneumothorax, pneumomediastinum, subcutaneous emphysema, false placement, hypoxia, bronchospasm, cardiac dysrhythmias, aspiration, and requirement of conversion to open surgical tracheostomy or even death. ${ }^{[3]}$ The patient's current medication, coagulation status, and mechanical circulatory support requirement may complicate the procedure, when PDT is required after cardiac surgery, particularly after a median sternotomy.

Fiberoptic bronchoscopy can be performed during the procedure to avoid complications such as posterior tracheal wall injuries or high placement of the tracheostomy tube and for optimum endotracheal placement ${ }^{[4]}$ However, the fact that bronchoscopy is not available in every intensive care unit (ICU) and due to its associated complications such as bleeding or thyroid punctures have led to the use of ultrasound (US) guidance in this area.

The most commonly used anatomical imaging is US. Using the US guidance, which is available in almost every ICU, cervical vascular anatomy, tracheal rings, and thyroid glands can be easily visualized. The beneficial effects of US for PDT regarding the procedure safety have been shown in several studies ${ }^{[5]}$ Nevertheless, the use of real-time US for PDT can be complicated in inexperienced hands. Pre-procedural US evaluation and measurements can increase the success of the procedure and reduce the complication rates.

Currently, the US is frequently used in the intensive care practice during PDT in critically ill patients. However, US-guided PDT use in patients undergoing a median sternotomy has not been reported to date. In the present study, we, therefore, aimed to compare US-guided PDT versus bronchoscopy-guided PDT in critically ill adult patients undergoing open heart surgery through a median sternotomy in terms of safety, efficacy, and procedural complications.

\section{PATIENTS AND METHODS}

This single-center, retrospective, case-control study was conducted at Ankara University Faculty of Medicine, Department of Cardiovascular Surgery between January $1^{\text {st }}, 2015$ and December $30^{\text {th }}, 2020$. A total of 54 patients (17 males, 37 females; mean age: $54.9 \pm 13.1$ years; range, 39 to 77 years) who underwent elective US- or bronchoscopy-guided PDT after a median sternotomy were included. The study population was a consecutive unselected series of patients and bronchoscopy-guided PDT patients were recruited as the controls. During the study period, a total of 2,159 sternotomies were performed at our institution. The overall incidence of tracheostomy requirement after sternotomy in our unit was $2.5 \%$. We included all consecutive adult patients who required tracheostomy following a median or upper-J sternotomy who were $\geq 18$ years old. Exclusion criteria were as follows: having minimally invasive or robotic surgery using mini-thoracotomy incisions; the presence of coagulopathy (international normalized ratio [INR] $>2$ ) or a platelet count of $<50 \times 10^{9} / \mathrm{L}$; and history of previous tracheostomy or cervical spinal injury. A written informed consent was obtained from each participant. The study protocol was approved by the Ankara University Faculty of Medicine Human Research Ethics Committee (I10-659-20). The study was conducted in accordance with the principles of the Declaration of Helsinki.

Data including age, sex, body mass index, operation types, date of ICU admission, date of the procedure, the Simplified Acute Physiology Score II (SAPS-II), Sequential Organ Failure Assessment (SOFA) scores, anatomical difficulties, and procedure-related complications were recorded.

\section{Tracheostomy procedure}

After the decision to perform PDT, antithrombotic drugs were discontinued and warfarin was replaced with low-molecular-weight heparin for the periods specified in the guidelines. Adequate sedation and neuromuscular blockade were applied to the patients who were connected to a mechanical ventilator. A total of $100 \%$ oxygen was given before the procedure to prevent hypoxia. A shoulder roll was employed in all patients.

\section{US-guided PDT}

In the US-guided technique, following patient positioning, pre-procedural US examination of the anterior neck was performed by an anesthesiologist who participated in US courses hold by the National Society of Anesthesiology and Reanimation as an instructor after attending to two international courses on airway US. A GE Vivid T8 portable US machine (GE Healthcare, Fairfield, CT, USA) with a 3 to $8 \mathrm{MHz}$ linear array probe at an average depth of $4 \mathrm{~cm}$ was used. 
Considering the tracheal space that can be punctured according to the landmark technique, appropriate tracheal space for PDT was determined in the sagittal plane view and it was recorded whether the puncture site was changed. The skin to trachea distance and the trachea's transverse diameter was measured on the transverse view of that tracheal space (Figure 1). These measurements were marked on the needle to be used. Thus, the first point to enter the lumen and the second to stop was identified (Figure 2). Besides, US evaluation helps to locate the cricothyroid membrane and tracheal rings, and the presence of any vascular structure or a mass anterior to the trachea. After local infiltration of lidocaine $\% 2$, the needle of the tracheostomy kit (Portex Ltd., Hythe, Kent, UK) was advanced up to the first mark on it, and the air was aspirated. It was, then, continued until the second mark and the cannula was advanced into the lumen. A J-tipped Seldinger wire was placed through the cannula. The cannula was pulled out and the soft tissue was dilated with the dilator sent through the wire. In the next step, the trachea was dilated with the help of guidewire dilator forceps according to the Griggs technique. Finally, the tracheostomy tube was advanced into the trachea. ${ }^{[6]}$

\section{Bronchoscopy-guided PDT}

In the bronchoscopy-guided technique, following patient positioning, the appropriate tracheal space was determined by physical examination. After local infiltration of lidocaine $\% 2$, the tracheostomy kit needle was advanced, until the air was aspirated. The position of the needle and guidewire was checked by fiberoptic bronchoscopy. Then, the process was continued according to the Griggs technique.

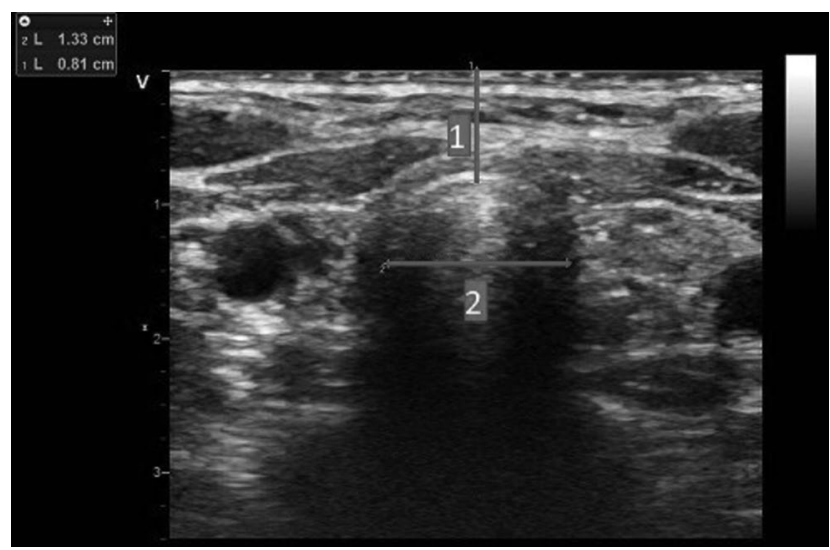

Figure 1. Transverse view trachea. 1. Skin to trachea distance; 2. Transverse diameter of the trachea.

\section{Outcome measures}

The primary outcome of this case-control study was to compare US-guided PDT versus bronchoscopyguided PDT in terms of procedure-related mortality and complications following PDT. In this context, the procedure-related complications were examined under two headings as major and minor. Major complications were defined as procedure-related death, cardiac arrest, tracheal wall injury, loss of airway, false passage cannulation, pneumothorax or pneumomediastinum, damage to adjacent structures (esophageal injury, tracheoesophageal fistula) conversion to surgical tracheostomy, hypotension requiring any intervention (fluids or vasopressors), acute hypoxemia (peripheral oxygen saturation below $90 \%$ for more than $5 \mathrm{~min}$ ), major bleeding requiring transfusion and/or surgical repair, tracheostomy related sepsis. A post-PDT chest radiograph was evaluated to exclude pneumothorax. Minor complications included transient hypotension (not requiring any intervention), desaturation less than 5 min, localized minor bleeding (self-limiting or treated with a local compression), localized subcutaneous emphysema, and local stomal infections not causing sepsis.

\section{Statistical analysis}

Statistical analysis was performed using the SPSS version 15.0 software (SPSS Inc., Chicago, IL, USA). Descriptive data were presented in mean \pm standard deviation (SD) or median (min-max) for quantitative variables and in number and frequency for qualitative variables. Parametric test assumptions were compared using the independent samples t-test or Mann-Whitney U test for quantitative variables, and using the chi-square or Fisher's exact test for qualitative variables. A $p$ value of $<0.05$ was considered statistically significant.

\section{RESULTS}

Of a total of 54 patients, 29 were included in the bronchoscopy-guided PDT group and 25 were included

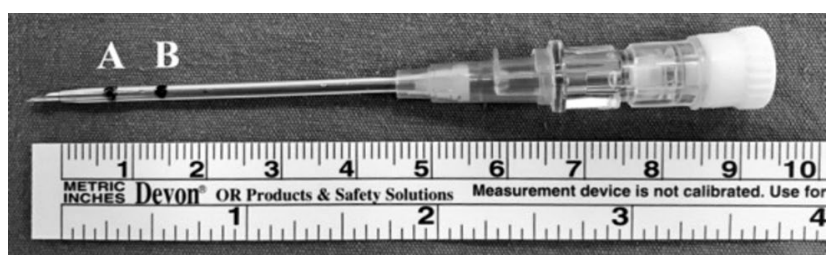

Figure 2. Marked needle for percutaneous dilatational tracheostomy. Needle tip - A: Measurement of skin-trachea distance; A-B: Measurement of radius of trachea; B: The point where the needle to be advanced maximally. 
in the US-guided PDT group. All tracheostomies were performed in the ICU. There were no significant differences in terms of baseline characteristics, types of previous surgeries, and suboptimal neck anatomy criteria (short neck and limited neck extension) between the patients who underwent two different PDT strategies (Table 1).

The mean skin-trachea distance was $9.2 \pm 1.9 \mathrm{~mm}$ and the mean tracheal diameter was $21.3 \pm 2.4 \mathrm{~mm}$ in the US-guided group. The puncture site was changed in five patients (\%20) due to vessels or thyroid beneath the puncture site. There was no statistically significant difference between the two groups in terms of the size of the tracheostomy cannula used and the duration of the procedure $(\mathrm{p}=0.664$ and $\mathrm{p}=387$, respectively). In addition, no significant difference in the number of tracheal punctures between the groups $(\mathrm{p}=0.678)$ (Table 2).

The median ICU length of stay was 18 days in both groups $(\mathrm{p}=0.361)$. The median hospital length of stay was 32 (range, 19 to 58) days in the bronchoscopyguided group and 33 (range, 21 to 63) days in the US-guided group $(\mathrm{p}=0.452)$. The patients in both groups were similar in terms of ICU mortality and hospital mortality $(20.6 \%$ vs. $24 \%$, respectively; $\mathrm{p}=0.522$ and $57 \%$ vs. $44 \%$, respectively; $\mathrm{p}=0.280$ ). There was no conversion between the PDT methods or conversion to surgical tracheostomy for any patient.

Overall procedural complication rate was $44.8 \%$ in the bronchoscopy-guided group and $24 \%$ in the US-guided group $(\mathrm{p}=0.155)$. Minor bleeding was seen

Table 1. Baseline characteristics of the patients and types of previous surgeries

\begin{tabular}{|c|c|c|c|c|c|c|c|c|c|c|}
\hline \multirow[b]{2}{*}{ Baseline characteristics } & \multicolumn{3}{|c|}{$\begin{array}{l}\text { Bronchoscopy-guided } \\
\text { PDT }(\mathrm{n}=29)\end{array}$} & \multicolumn{3}{|c|}{$\begin{array}{l}\text { US-guided } \\
\text { PDT (n=25) }\end{array}$} & \multicolumn{3}{|c|}{$\begin{array}{c}\text { Total PDT } \\
(\mathrm{n}=54)\end{array}$} & \multirow[b]{2}{*}{$p$} \\
\hline & $\mathrm{n}$ & $\%$ & Mean \pm SD & $\mathrm{n}$ & $\%$ & Mean \pm SD & $\mathrm{n}$ & $\%$ & Mean \pm SD & \\
\hline Age (year) & & & $55.6 \pm 13.3$ & & & $53.8 \pm 12.7$ & & & $54.9 \pm 13.1$ & 0.532 \\
\hline \multicolumn{11}{|l|}{ Sex } \\
\hline Male & 9 & 31 & & 8 & 32 & & 17 & 31.5 & & 0.330 \\
\hline $\operatorname{BMI}\left(\mathrm{kg} / \mathrm{m}^{2}\right)$ & & & $25.1 \pm 6.9$ & & & $26.2 \pm 6.3$ & & & $25.6 \pm 6.7$ & 0.715 \\
\hline $\mathrm{BMI}(\geq 30)$ & 4 & 13.7 & & 4 & 16 & & 8 & 14.8 & & \\
\hline EuroSCORE II (\%) & & & $9.3 \pm 7.9$ & & & $10.1 \pm 6.7$ & & & $9.8 \pm 8.4$ & 0.451 \\
\hline SAPS II & & & $46 \pm 12.8$ & & & $48 \pm 13.1$ & & & $47 \pm 12.9$ & 0.426 \\
\hline SOFA-ICU score & & & $10 \pm 2.4$ & & & $11 \pm 2.6$ & & & $10 \pm 2.5$ & 0.642 \\
\hline $\begin{array}{l}\text { Days on mechanical ventilation } \\
\text { before PDT }\end{array}$ & & & $13 \pm 2.7$ & & & $15 \pm 1.6$ & & & $14 \pm 2.1$ & 0.172 \\
\hline Types of previous surgeries & & & & & & & & & & 0.347 \\
\hline CABG & 3 & 10.3 & & 3 & 12 & & 6 & 11.1 & & \\
\hline Aortic valve replacement & 3 & 10.3 & & 2 & 8 & & 5 & 9.2 & & \\
\hline Mitral valve replacement & 2 & 6.8 & & 1 & 4 & & 3 & 5.5 & & \\
\hline Multiple valve replacement & 7 & 24.1 & & 6 & 24 & & 13 & 24 & & \\
\hline CABG + valve replacement & 8 & 27.5 & & 6 & 24 & & 14 & 25.9 & & \\
\hline Aortic dissection & 5 & 17.2 & & 5 & 20 & & 10 & 18.5 & & \\
\hline LVAD and/or ECMO/RVAD & 1 & 3.4 & & 2 & 8 & & 3 & 5.5 & & \\
\hline Suboptimal neck anatomy & & & & & & & & & & 0.456 \\
\hline None & 25 & 86.2 & & 21 & 84 & & 46 & 85.1 & & \\
\hline Short neck & 3 & 10.3 & & 3 & 12 & & 6 & 11.1 & & \\
\hline Limited neck extension & 1 & 3.5 & & 1 & 4 & & 2 & 3.7 & & \\
\hline
\end{tabular}

PDT: Percutaneous dilatational tracheostomy; US: Ultrasound; SD: Standard deviation; BMI: Body mass index; EuroSCORE: European System for Cardiac Operative Risk Evaluation; SAPS II: Simplified Acute Physiology Score-II; SOFA: Sequential Organ Failure Assessment; ICU: Intensive care unit; CABG: Coronary artery bypass grafting; LVAD: Left ventricular assist device; ECMO: Extracorporeal membrane oxygenation; RVAD: Right ventricular assist device. 

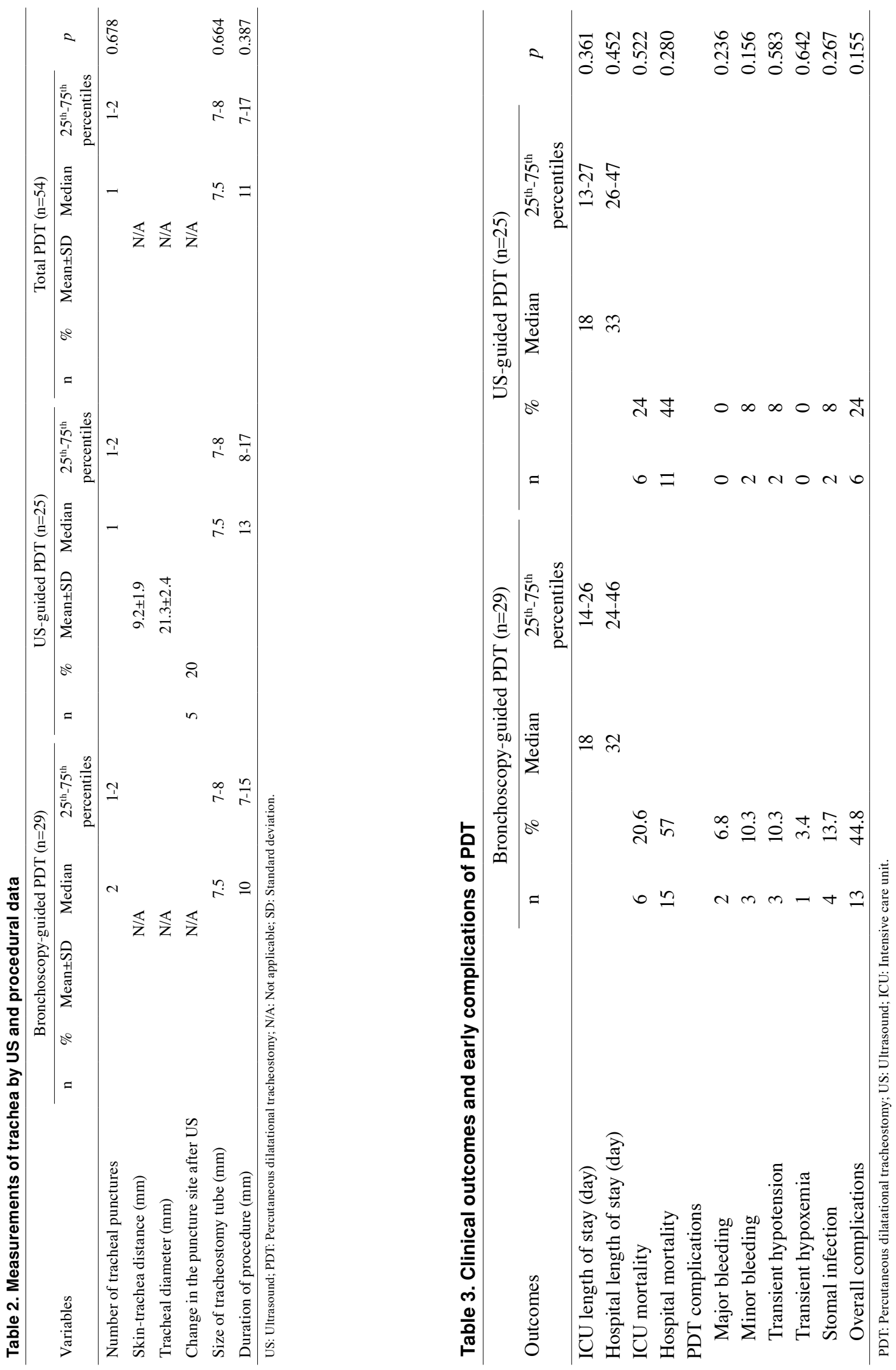
in $10.3 \%$ in the bronchoscopy-guided group and $8 \%$ in the US-guided group $(\mathrm{p}=0.156)$. Major bleeding was observed in $6.8 \%$ of the bronchoscopy-guided group, while no major bleeding was observed in the US-guided group $(\mathrm{p}=0.236)$. There was no significant difference between the two groups in terms of transient hypotension $(10.3 \%$ vs. $8 \%$, respectively; $\mathrm{p}=0.583)$ and transient hypoxemia $(3.4 \% v s .0 \%$, respectively; $\mathrm{p}=0.642$ ). After the procedure, stomal infection was observed with a rate of $13.7 \%$ in the bronchoscopyguided group, while this rate was $8 \%$ in the US-guided group $(\mathrm{p}=0.267)$ (Table 3$)$. No cardiac dysrhythmias or cardiac arrest, airway loss, tracheal wall injury or tracheal ring fracture, damage to adjacent structures, pneumothorax or pneumomediastinum, subcutaneous emphysema, bronchospasm, aspiration, false placement of the cannula or tracheostomy procedure-related death was identified.

\section{DISCUSSION}

Ultrasound guidance is as practical as bronchoscopy guidance in patients undergoing PDT after sternotomy in terms of safety, efficacy, and procedural complications. It has comparable complication rates to a gold-standard technique such as bronchoscopy, without prolonging the procedure time. Although there was no statistically significant difference in the complication rates, the absence of major bleeding with US-guided PDT keeps this technique one step ahead. It may have caused this by changing the puncture site in $20 \%$ of the patients.

Most patients undergoing cardiac surgery are extubated within the first three days. ${ }^{[7]}$ However, elective tracheostomy has been used safely for many years in those who need prolonged intubation to avoid chronic endotracheal intubation complications. ${ }^{[8]}$ Although surgical tracheostomy is preferred in a small proportion of patients, bedside PDT has become the gold standard in terms of safety and cost. ${ }^{[9]}$ Bacchetta et al. ${ }^{[9]}$ reported that PDT offered significant cost savings without a clinical difference between the two techniques in the cardiothoracic surgical practice. Since there is no need to transfer the patients to the operating room, PDT also ensures more effective use of the limited staff and cost savings. In particular, in patients with extracorporeal supportive therapy, this becomes an even more important advantage.

In addition to conventional and bronchoscopyguided techniques, US has been used frequently for PDT in recent years. Although the traditional approach has been compared to both methods, imaging methods such as bronchoscopy or US have come to the fore to reduce the complication rates. Gobatto et al. ${ }^{[10]}$ first demonstrated in a retrospective cohort study that US-guided PDT was safe with similar complication rates to the bronchoscopy-guided group. Later, they showed that US-guided PDT was non-inferior to the bronchoscopy-guided group in mechanically ventilated critically ill patients with a randomized non-inferiority controlled trial. ${ }^{[11]}$ Our study is the first to evaluate these two techniques in PDT after a median sternotomy. The findings suggest that the US-guided PDT is at least as safe as the bronchoscopy-guided PDT.

Furthermore, PDT has many complications, and the most fatal is bleeding. ${ }^{[12]}$ In addition to venous bleeding, arterial bleeding can be also seen. Moreover, aortic arch injury has been reported as an infrequent complication. ${ }^{[13]}$ In this context, anticoagulation and continuation of heparinization are both debated in cardiac surgery patients, particularly in patients who require extracorporeal life support. Bektas et al. ${ }^{[14]}$ reported that PDT could be applied safely in patients with extracorporeal membrane oxygenation and/or left ventricular assist device, and no significant complications were encountered in the bedside PDT procedure in the patients with a mean INR value of 2 to 3. Although they reported no major bleeding, it was seen in two patients in the bronchoscopy group in our study, suggesting that caution should be exercised. These two patients who were operated on for ascending aortic dissection may indicate that more attention should be paid to this patient group. Since anticoagulant therapy can be applied after cardiac surgery, the importance of US emerges. Although there was no statistically significant difference in complication rates, the absence of major bleeding with US-guided PDT indicates that this is a protective factor. It may have caused this by changing the puncture site in $20 \%$ of the patients. Even-Tov et al. ${ }^{[15]}$ also published that pre-procedural US can influence the decision of surgical or bedside PDT and this choice could lead to increase the safety of procedure. The ability to select the most appropriate tracheal interspace with prepuncture evaluation can be considered an advantage of US over bronchoscopy.

One of the most important complications of PDT is posterior wall perforation with esophageal injury. ${ }^{[16]}$ Although rare in experienced hands, bronchoscopy guidance is the gold standard to avoid this complication. Balaban et al. ${ }^{[17]}$ reported in their case series that they successfully completed the PDT procedure under US guidance and accompanied by bronchoscopy in three patients, one of whom was operated for aortic dissection, one patient with trauma 
and one with hypoxic encephalopathy. As US may be ineffective in visualizing the posterior part of trachea due to reverberation and acoustic shadow artifacts, complications can be avoided with the radius measurement technique we described. Assuming that the trachea has a circular structure, inserting the needle as much as the radius length can prevent posterior wall injury. The absence of posterior wall injury in both groups proves that US is at least as effective as bronchoscopy.

Another complication that should be considered for tracheostomy performed after sternotomy is sternal wound and stomal infections. Pilarczyk et al. ${ }^{[18]}$ reported in a retrospective study that PDT within the first 10 postoperative days after cardiac surgery with a median sternotomy could be performed safely without an increased risk of deep sternal wound infection. Besides, Byhahn et al. ${ }^{[19]}$ found that there was no relationship between colonization detected in the airway and sternal infection, suggesting that tracheostomy should not be delayed in patients who require prolonged mechanical ventilation after sternotomy. In a comprehensive meta-analysis, Toeg et al. ${ }^{[20]}$ reported that sternal wound infection could be seen after tracheostomy in patients undergoing sternotomy, although they found no significant difference between the surgical or percutaneous technique. While no sternal wound infection was observed in our study, there was no significant difference between the groups in terms of stomal infection. However, further prospective, randomized studies are needed to reach accurate data and to reveal the relationship between timing or technique of tracheostomy and sternal infection.

This study has several limitations. First, in this case-control study, participants were recruited from the hospital database based on the PDT procedure after a sternotomy performed at cardiac ICU; however, casecontrol studies may also be prone to selection bias and recall bias. Second, PDT complications are rarely seen, and a small sample size may not allow a statistically significant difference in complication rates between the groups. Third, although US-guided PDTs are performed by a single anesthesiologist, bronchoscopyguided procedures were performed by different anesthesiologists or surgeons with experiences, which may cause bias in evaluation. Finally, since the patients were not followed after discharge, no assessment could be made for chronic complications of PDT.

In conclusion, ultrasound-guided percutaneous dilatational tracheostomy can be safely performed in patients undergoing sternotomy. Complication rates of the procedure are similar to those guided with bronchoscopy. In contrast with the limited access of bronchoscopes and their inability to determine the structures anterior to the trachea, ultrasound is readily available in most of the intensive care units, is noninvasive, and is able to visualize all structures adjacent to the trachea.

\section{Acknowledgments}

We are grateful to the intensive care unit staff of Department of Cardiovascular Surgery of Ankara University Faculty of Medicine.

\section{Declaration of conflicting interests}

The authors declared no conflicts of interest with respect to the authorship and/or publication of this article.

\section{Funding}

The authors received no financial support for the research and/or authorship of this article.

\section{REFERENCES}

1. Freeman BD, Morris PE. Tracheostomy practice in adults with acute respiratory failure. Crit Care Med 2012;40:2890-6.

2. Ruohoalho J, Xin G, Bäck L, Aro K, Tapiovaara L. Tracheostomy complications in otorhinolaryngology are rare despite the critical airway. Eur Arch Otorhinolaryngol 2021.

3. Durbin CG Jr. Techniques for performing tracheostomy. Respir Care 2005;50:488-96.

4. Rajajee V, Fletcher JJ, Rochlen LR, Jacobs TL. Real-time ultrasound-guided percutaneous dilatational tracheostomy: A feasibility study. Crit Care 2011;15:R67.

5. Song J, Xuan L, Wu W, Zhu D, Zheng Y. Comparison of percutaneous dilatational tracheostomy guided by ultrasound and bronchoscopy in critically Ill obese patients. J Ultrasound Med 2018;37:1061-9.

6. Park SS, Goldenberg D. Percutaneous tracheotomy: Griggs technique. Operative Techniques in Otolaryngology-Head and Neck Surgery 2007;18:95-8.

7. Trouillet JL, Combes A, Vaissier E, Luyt CE, Ouattara A, Pavie A, et al. Prolonged mechanical ventilation after cardiac surgery: outcome and predictors. J Thorac Cardiovasc Surg 2009;138:948-53.

8. Tewarie L, Zayat R, Haefner H, Spillner J, Goetzenich A, Autschbach R, et al. Does percutaneous dilatational tracheostomy increase the incidence of sternal wound infection - a single center retrospective of 4100 cases. J Cardiothorac Surg 2015;10:155.

9. Bacchetta MD, Girardi LN, Southard EJ, Mack CA, Ko W, Tortolani AJ, et al. Comparison of open versus bedside percutaneous dilatational tracheostomy in the cardiothoracic surgical patient: Outcomes and financial analysis. Ann Thorac Surg 2005;79:1879-85.

10. Gobatto AL, Besen BA, Tierno PF, Mendes PV, Cadamuro F, Joelsons D, et al. Comparison between ultrasound- and bronchoscopy-guided percutaneous dilational tracheostomy in critically ill patients: A retrospective cohort study. J Crit Care 2015;30:220.e13-7. 
11. Gobatto ALN, Besen BAMP, Tierno PFGMM, Mendes PV, Cadamuro F, Joelsons D, et al. Ultrasound-guided percutaneous dilational tracheostomy versus bronchoscopyguided percutaneous dilational tracheostomy in critically ill patients (TRACHUS): A randomized noninferiority controlled trial. Intensive Care Med 2016;42:342-51.

12. McCormick B, Manara AR. Mortality from percutaneous dilatational tracheostomy. A report of three cases. Anaesthesia 2005;60:490-5.

13. Ulatowski N, Karolak W, Łoś A, Kołaczkowska M, Siondalski P. Iatrogenic aortic arch injury after unsuccessful percutaneous tracheostomy. J Card Surg 2020;35:686-8.

14. Bektaş Ş, Çavuş M, Turan S. Percutaneous dilatational tracheostomy in patients with mechanical circulatory support: Is the procedure safe? Turk Gogus Kalp Dama 2020;28:435-41.

15. Even-Tov E, Koifman I, Rozentsvaig V, Livshits L, Gilbey P. Pre-procedural ultrasonography for tracheostomy in critically Ill patients: A prospective study. Isr Med Assoc J 2017;19:337-40.
16. Bathula SS, Srikantha L, Patrick T, Stern NA. Immediate postoperative complications in adult tracheostomy. Cureus 2020;12:e12228.

17. Balaban O, Acar A, İtal İ, Aydın T. Ultrasonografi kılavuzluğunda ve fiberoptik bronkoskopi eşliğinde perkütan trakeostomi açılması. Turkiye Klinikleri J Anest Reanim 2018;16:41-6.

18. Pilarczyk K, Marggraf G, Dudasova M, Demircioglu E, Scheer V, Jakob H, et al. Tracheostomy after cardiac surgery with median sternotomy and risk of deep sternal wound infections: Is it a matter of timing? J Cardiothorac Vasc Anesth 2015;29:1573-81.

19. Byhahn C, Rinne T, Halbig S, Albert S, Wilke HJ, Lischke $\mathrm{V}$, et al. Early percutaneous tracheostomy after median sternotomy. J Thorac Cardiovasc Surg 2000;120:329-34.

20. Toeg H, French D, Gilbert S, Rubens F. Incidence of sternal wound infection after tracheostomy in patients undergoing cardiac surgery: A systematic review and meta-analysis. J Thorac Cardiovasc Surg 2017;153:1394-400.e7. 